\title{
Subcutaneous bronchogenic cyst in a child: case report
}

\author{
Esperança Vidal Quipungo ${ }^{a}$, Giuliano Campolim Gagliottia, \\ Aloísio Felipe-Silva ${ }^{b}$, Ricardo Frank Coelho da Rocha ${ }^{a}$
}

Gagliotti GC, Quipungo EV, Felipe-Silva A, Rocha RFC. Subcutaneous bronchogenic cyst in a child: case report. Autopsy Case Rep [Internet]. 2012;2(2):49-51. http://dx.doi.org/10.4322/acr.2012.017

\section{ABSTRACT}

\begin{abstract}
Bronchogenic cysts are congenital anomalies originating from the primitive tracheobronchial tree in the fetal period. Although the middle mediastinum is the site most commonly affected (second only to the lungs), there have been reports of bronchogenic cysts at unusual sites, such as the retroperitoneum. We report the case of a 4-year-old boy with a cystic mass in the left scapular area since birth. The cyst grew progressively and was accompanied by recurrent episodes of local infection requiring drainage. It was then surgically removed. The histological findings were decisive for the diagnosis: a subcutaneous cyst lined by ciliated columnar epithelium and surrounded by a fibrous wall with smooth muscle tissue, cartilage, and bronchial glands. We also found chronic inflammatory infiltrate, which is consistent with previous episodes of infection. Bronchogenic cysts should be included in the differential diagnosis of cystic tumors of the chest wall and neck, particularly in children. Surgery is the treatment of choice because of the risk of infection, as in this case, and of malignant degeneration.
\end{abstract}

Keywords: Bronchogenic cyst; Skin; Scapula; Surgery.

\section{INTRODUCTION}

Bronchogenic cysts constitute a benign congenital anomaly that originates from the primitive tracheobronchial tree in the fetal period. The middle mediastinum is the site that is most commonly affected (second only to the lungs), bronchogenic cysts being rarely found at other sites.

We report the case of a 4-year-old boy with a subcutaneous tumor in the left scapular region since birth. The tumor grew progressively and was accompanied by recurrent episodes of local infection requiring drainage, the boy having undergone surgical excision of the lesion. The histological findings were decisive for the diagnosis.

Bronchogenic cysts should be included in the differential diagnosis of congenital cysts and nodular lesions in the thoracic, dorsal, and cervical regions. Because of the risk of infection and malignancy, surgery is the treatment of choice.

\footnotetext{
${ }^{a}$ Department of Surgery - Hospital Universitário - Universidade de São Paulo, São Paulo/SP - Brazil.

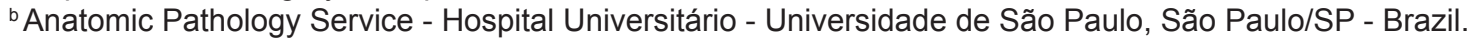

Copyright (c) 2012 Autopsy and Case Reports - This is an Open Access article distributed of terms of the Creative Commons Attribution NonCommercial License (http://creativecommons.org/licenses/by/3.0/) which permits unrestricted non-commercial use, distribution, and reproduction in any médium provided article is properly cited. 


\section{CASE REPORT}

We report the case of a 4-year-old boy with a subcutaneous lesion in the left scapular region since birth. The lesion grew progressively and indolently, being accompanied by three episodes of local infection requiring drainage, a large quantity of purulent secretion having been removed.

The lesion was excised en bloc-the skin ellipse being strongly adhered to the adjacent skin because of previous infectious processes-and sent for pathological examination. Macroscopic examination revealed a strip of skin measuring $4.5 \times 3.0 \mathrm{~cm}$, the epidermis being flattened. Dissection revealed a $3.0 \mathrm{~cm}$ cystic lesion with a brownish viscous liquid and shiny, irregular internal walls. Histology revealed that the lesion was located in the subcutaneous tissue and had fibrous tissue walls (Figure 1A). The lesion was found to be lined by pseudostratified ciliated columnar epithelium, typical of the bronchial mucosa, with lymphoid tissue arranged in follicles (Figure 1D). Other findings included smooth muscle tissue (Figure 1B), as well as cartilage and seromucous glands typical of the respiratory mucosa (Figure $1 \mathrm{C}$ ). Moderate mixed inflammatory infiltrate was found in the subepithelial connective tissue, the epithelium being permeated by lymphocytes and neutrophils, which were consistent with previous episodes of infection/ inflammation.

\section{DISCUSSION}

The first case of cutaneous bronchogenic cyst (CBC) was described by Seibold and Clagett in $1945 .{ }^{1}$ Since then, approximately 70 cases have been reported in the literature, most having been reported by dermatologists and pathologists. ${ }^{2} \mathrm{~A}$ rare entity, $\mathrm{CBC}$ is most common in children, the true incidence of $\mathrm{CBC}$ being unknown. ${ }^{2,3}$

Bronchogenic cysts originate from abnormal budding of the tracheal diverticulum of the foregut during the embryonic period. ${ }^{2}$ An anomaly that remains largely unknown, a bronchogenic cyst

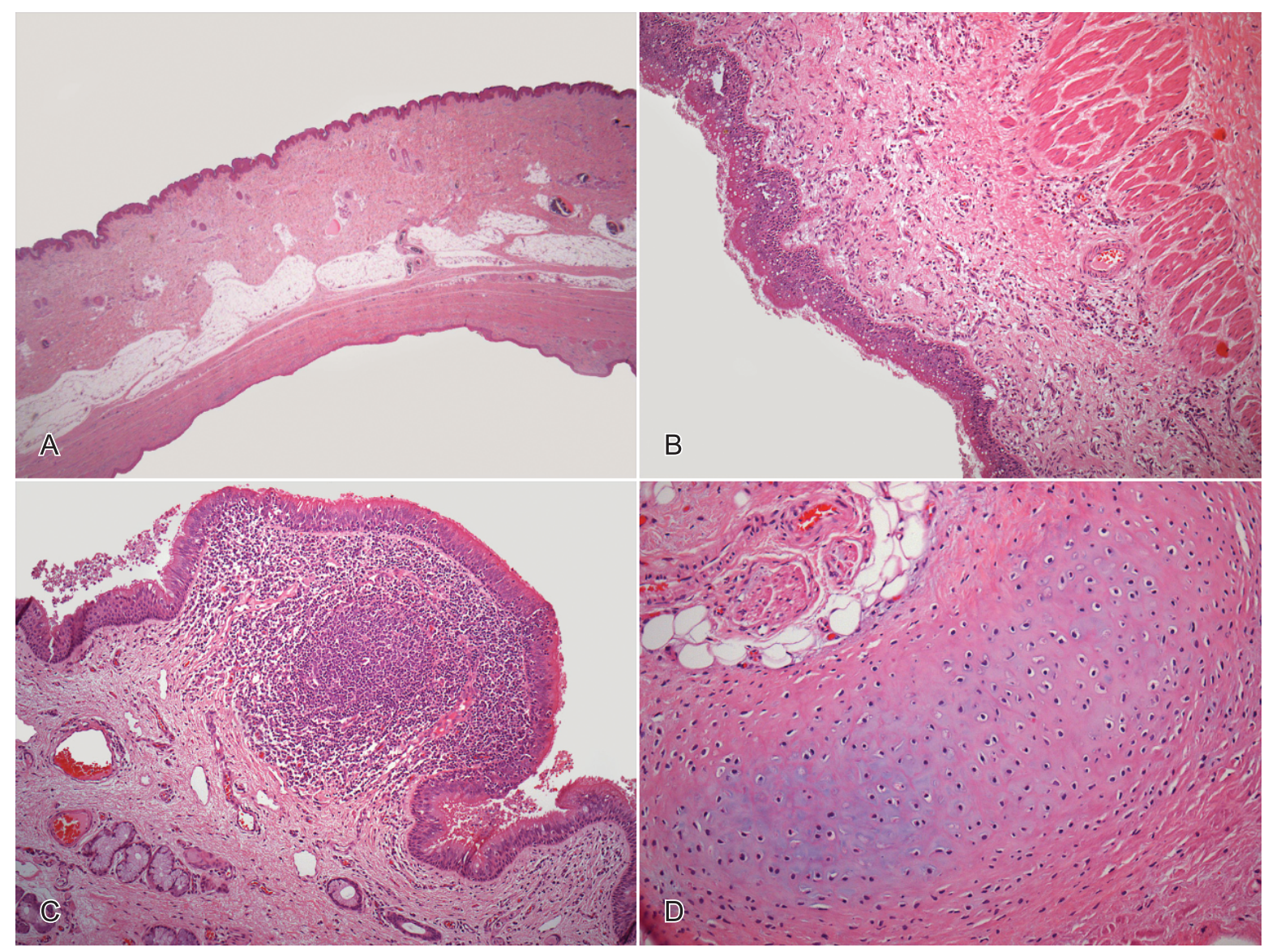

Figure 1 - Photomicrography - A - (HE-25x) Cyst lesion with fibrous wall in the subcutaneous tissue (bottom); B - (HE-200x) Detail of bronchogenic cyst epithelium showing ciliated pseudostratified columnar epithelium (respiratory type) and smooth muscle; C - (HE-200x) Lymphoid tissue beneath the respiratory epithelium. Note mucous glands in the bottom left; D - (HE-400x) Mural cartilaginous tissue was detected at microscopic examination. 
is diagnosed exclusively by histopathological examination, given that the clinical and radiological findings are nonspecific. ${ }^{4}$ Because bronchogenic cysts are typically located in the sternal and cervical regions, they are usually mistaken for branchial cleft cysts.

In 1948, Maier classified bronchogenic cysts into five groups by location: paratracheal cysts; carinal cysts; hilar cysts; paraesophageal cysts; and atypical cysts, which include diaphragmatic, abdominal, cutaneous, subcutaneous, and supraclavicular cysts. ${ }^{5}$ Two main theories have been postulated to explain the development of CBCs. According to the first theory, the bronchogenic cyst, arising from the developing tracheal bud, is left out of the thorax after sternal closure at gestational week 9 and migrates to the skin. According to the second theory, known as the "pinch-off" theory, the cyst simply pinches off from the developing tracheal bud during the closure of the mesenchymal plates, the cyst and the bud growing simultaneously. ${ }^{2,6}$

In most cases, there is no communication between the cyst and the thoracic cavity. Because CBCs are mostly solitary, the pinch-off theory seems to explain their occurrence in most cases. ${ }^{2}$

These lesions are four times as common in males as they are in females, and the site that is most commonly affected is the sternal notch, followed by the presternal area, the cervical area, and, more rarely, the scapular area. ${ }^{5}$ The pathological diagnosis is based on the finding of one or more tracheobronchial structures in the cyst wall. ${ }^{2}$ Hyaline cartilage, smooth muscle cells, elastic fibers, fibrous tissue, and seromucous glands are common findings. ${ }^{7}$

Surgical excision is the treatment of choice, which is due to the risk of infection (as was the case in our patient) and degeneration to malignant melanoma or mucoepidermoid carcinoma. ${ }^{2,5,8}$ The differential diagnosis of bronchogenic cyst in the scapular region includes lymphangioma, epidermoid cysts, and other sebaceous cysts. ${ }^{5}$ Complete excision is curative.

\section{REFERENCES}

1. Adim SB, Baskan EB, Saricaoglu H, Elezoglu B. Cutaneous heterothopic bronchogenic tissue in the scapular area. Australas J Dermatol. 2010;51(1):42-4. PMid:20148842. http://dx.doi.org/10.1111/j.1440-0960.2009.00591.x

2. Ozel SK, Kazez A, Koseogullari AA, Akpolat N. Scapular bronchogenic cysts in children: case report and review of the literature. Pediatr Surg Int. 2005;21(10):843-5. PMid:16180006. http://dx.doi.org/10.1007/s00383-005-1531-5

3. Nakamura Y, Fujishima F, Ito $S$, et al. A case of cutaneous bronchogenic cyst in the scapular area. Pol J Pathol. 2011;62(2):120-1. PMid:21866472.

4. Zvulunov A, Amichai B, Grunwald MH, Avionach I, Halevy S. Cutaneous bronchogenic cyst: delineation of a poorly recognized lesion. Pediatr Dermatol. 1998;15(4):277-81. PMid:9720691. http://dx.doi.org/10.1046/ j.1525-1470.1998.1998015277.x

5. Gaikwad P, Muthusami JC, Raj JP, Rajinikanth J, John GM. Subcutaneous bronchogenic cyst. Otolaringol Head Neck Surg. 2006;135(6):951-2. PMid:17141090. http://dx.doi. org/10.1016/j.otohns.2006.05.032

6. Miller 3rd OF, Tyler W. Cutaneous bronchogenic cyst with papilloma and sinus presentation. J Am Acad Dermatol. 1984;11(2 pt. II):367-71. http://dx.doi.org/10.1016/ S0190-9622(84)70175-7

7. Magnussen JR, Thompson JN, Dickinson JT. Presternal bronchogenic cysts. Arch Otolaryngol. 1977;103(1):52-4. http://dx.doi.org/10.1001/archotol.1977.00780180090013

8. Tanita M, Kikuchi-Numagami K, Ogoshi K, et al. Malignant melanoma arising from cutaneous bronchogenic cyst of the scapular área. J Am Acad Dermatol. 2002;46(2 Suppl Case Reports):S19-21.

\section{Conflict of interest: None}

Submitted on: $7^{\text {th }}$ May 2012

Accept on: $24^{\text {th }}$ May 2012

Correspondence: Divisão de Clínica Cirúrgica

Av. Prof. Lineu Prestes, 2565 - Cidade Universitária - São Paulo/SP - Brazil

CEP: 05508-000 - Phone: +55 (11) 3091-9291

E-mail: panchapretty84@yahoo.com.br 
